\title{
ACTION PLAN OF A TEACHER IN HIS/HER OWN CLASS
}

\author{
Jana Trabalíková
}

\begin{abstract}
This paper informs about the action plan of a teacher in his/her own class. It focuses on one of the possible approaches how to explore the quality of class environment as a factor of the education-formation strategy efficacy in real conditions of a Slovak primary school during the implementation of cooperative teaching. By the means of diagnosing mutual relations among pupils, and the changes in the sociometric structure of groups, it reviews the changes in their prosocial behaviour. It describes the research, which compares by sociometric measures the diagnosable differences in the dynamics of social relations in an experimental and controlled group created by 144 pupils of the $5^{\text {th }}$ year of a primary school. After analysing the acquired data from the sociometric measures, it brings a piece of knowledge that if a teacher at the second grade of primary schools wants to influence the social climate in classes and does not have the support from colleagues, his efforts need not cause an expected effect. Even due to this it emphasizes the fact that if there are to be innovations at our schools, they should be systemic and elaborated, they should be intermingled with all teaching subjects.
\end{abstract}

\section{Key words}

Action research, practical research, sociometry, sociograms, sociometric matrix, socio-preferential relations, social skills.

\section{Cooperative strategy and socio-preference relations in a school class}

Wardová (1995, p. 460) perceives a teacher as a teaching leader in a class with the strength to help pupils develop qualities, personality relations and professional-working interests, and to help pupils develop their knowledge and emotions with a competence. It is necessary for a teacher to know the information about the social environment in a class. In this connection Wardová identifies the notion of class environment with the term "climate", and calls it a blend of how pupils interact among themselves and with a teacher. The quality of class environment as a factor of the education-formation strategy 
efficacy was, in the research activities carried out in the USA, proved to be a precondition for increasing a quality level and amount of learnt teaching load. It was confirmed that the learning with deep understanding appears if pupils and a teacher cooperate together. This mostly appears in a cooperative learning, where a bidirectional and multichannel communication is at the same time being improved.

So, the cooperative teaching has also an influence on one of the components of the social-psychological teaching climate - the communication climate, and it can direct the climate from the nondescript and defensive climate defined by Rosenfeld at the beginning of the 1980s to the supporting one. The Lašek's research (1994, p. 156) based on the sample of 924 students of the third year at secondary schools clearly confirmed the irreplaceable role of a teacher as a creator of the communicative climate in a class. Since it is also Zelina (1996, p. 155), who considers influencing the class climate as one of the primary professional acts of an educator, and in this connection deals with the tactics of a pedagogue participating in its influence, the school climate became a phenomenon for us, which influences the efficacy of the educational process, and is connected with social relations in a class (Fig. 1). In our research, by the means of cooperative tasks, we have deliberately focused on specifically developing the social skills of students, which need to be, according to Siegrist (2001, p. 27), related to a certain content.

Fig. 1: Cycle of the cooperative teaching functioning

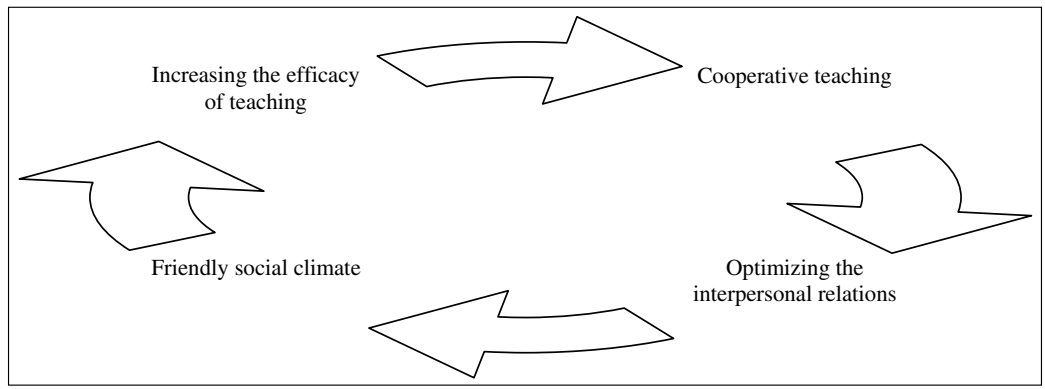

We have carried out a practical research, which is presented by Murphy $(1995$, p. 469) as a way to help solve problems in a class, support an efficient innovation. In the present times, teachers cannot perceive research as 
something belonging to higher education institutions and statisticians. In this way, we have applied the studying of the professional literature in practice, respecting the value of our own participation in the research focused on specific aspects of teaching. The possibility of applying research observations in one's own practice is invaluable.

Seebauer (2005) explains that the perception and evaluation of a certain situation, together with the adequate education strategies of coping with it, needs to be viewed in connection with the factors of the concept of its own, and with a social net of the educated. Švec (1995) defines the three levels of a systemic observation of education: social, institutional and personal one. From the personal point of view where education is considered as a relation among the educating and the educated, leading to the purposive development and self-development of a personality, he emphasizes the present-day nonone-sidedness of personality approaches. It is the self-realization of a man as a main point of education that is being presented in them, however, the man can carry out the self-realization just in a human society, that is not just for his/her own benefit, but also for the benefit of others.

In this sense we stress that by the interaction in cooperative teaching the self-realization of a child is being achieved not just under the influence of a teacher, but also under the influence of a performance related to the rest of a group and acquired feedback. The educator exposes the educated, through the induced cooperative situations, to the educating moments, which lead to accepting responsibility for their own acts. We follow the intentions of the process, which is in case of a child defined by Kosová (2007, p. 44) as "a productive creation of oneself".

Fig. 2: Net of social relations in a traditional and cooperative teaching

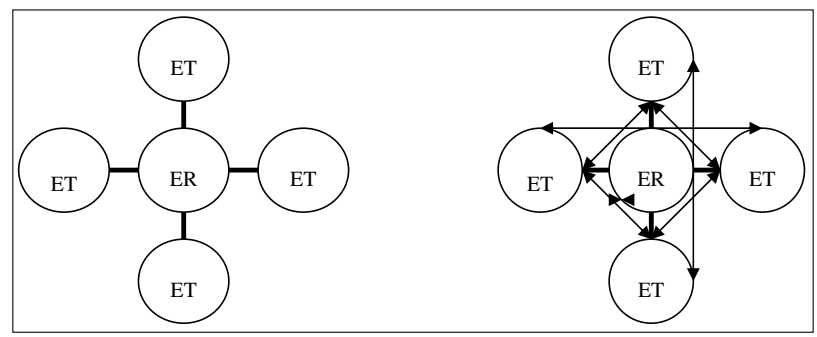

ER - educator, ET - educated 
In relation to this, the humanistic pedagogy mentions the teaching "centred by a pupil”, i.e. self-organized teaching (Rogers-Freiberg in: Kosová, 2007, p. 47). The social development of a child and an individual choice are linked if such methods are used in which a child is as independently active as possible, but also the methods in which a child has to cooperate with others. On the basis of the sample of 440 pupils at the age of 10-11, Gillies - Ashman (1995) found out that when the pupils worked cooperatively in groups at a lesson three times a week in the period of 6 weeks, they became more compact and inclined to reach a group goal, the more opportunities they had for the collective work. However, the first two meetings were primarily assigned for getting familiar with activities, a group teaching process, practising the active listening to a speaker, how to formulate flexibly and clearly their ideas, how to criticise constructively the others' ideas, how to accept the responsibility for their own behaviour, how to solve problems democratically, how to clarify the differences in ideas, how to try to look at things from the perspective of others, how to rotate, etc. Not dependent on a group composition (from the point of view of abilities, sex), the pupils benefited from the experience of the cooperative work, and learned quickly how to work effectively, they were becoming more sensitive to common needs, and acquired the satisfaction in the progress and the results of cooperative activities. In another study, Gillies - Ashman (1998) found out that in the cooperative work pupils develop not just the ability to share the understanding of questions, but also the understanding towards the unexpressed needs of others in a group. Similar results were brought by Spencer et al. (2008). According to their students, the engagements in the work on projects improved relations among the other participants, and influenced what they thought of others if they set up contacts with people, who were different. They also found out that the students increased the desire to solve conflicts instead of ignoring them.

However, it is necessary to realize that small groups are a self-regulating system. If a conflict between the dynamism of a group and an individual grows, the system becomes stiff (McGeehan et al., 2008). Greer-Jehn-Mannix (2008) point to the negative and long-term impact of the conflicts discovered in the earlier phase of the group functioning. These kinds of conflicts (misunderstandings) lead to a higher appearance of all the other kinds of conflicts during the remaining interaction in a team. In the other types of conflicts concerning the mutual relations in a group or in discussed tasks, this impact was not found. The influence of this limiting factor may be, however, limited 
if the members of groups are able to solve the mentioned conflict at the beginning of the work.

In connection to building and growing mutual relations, and maintaining the mental health, social skills are directly related. The life quality of an individual is often dependent on their quality (Johnson-Johnson, 1990). In case of expecting the development of pupils in the area of prosocial and cooperative behaviour, Cohen (1994) points to the significance of a thorough planning and selection of techniques. She points to the fact that the status of a pupil correlates with the interaction in a small group, and vice versa, the interaction has a relation to the achieved knowledge of a pupil.

The sociometric status of an individual is defined in this connection as the signs of the individual evaluated by society. In relation to them, it is presupposed that it is better to have a high position than a low position. Influencing the status of an individual is a process when the status position affects the interaction in such a way that the prestige and value of the group reflect the beginning figure of the status. If a teacher presents cooperative tasks to the group, the status differences based on the level of knowledge are getting active and becoming related to a new situation even if the task does not require knowledge as such. In this situation, the pupils with a higher sociometric status find themselves more competent to solve the task and the same is expected from them by the group. In harmony with the expectations, the prophecy is again being fulfilled in a spell circle; the pupils with a higher level of knowledge are more active than the pupils with a lower level of knowledge. The discrimination of pupils with the lower level of knowledge can be then compared with the discrimination of pupils of other ethnicity, race or gender. That is why, from the point of view of a pedagogue, it is necessary to manage the situation by:

a) Providing tasks requiring different abilities (ability to solve problems, to reason). The members of a group can then perceive that each of them has certain abilities and none of them has all the abilities necessary for the elaboration of a task.

b) Assigning tasks to the pupils with a lower sociometric status. From the point of view of a pedagogue, it is inevitable to diagnose specific qualities, which are characteristic for an individual, and to consider to what extend they are suitable for using them in a group.

Cohen supports an opinion that for the purposes of maximizing the productivity of learning it is necessary to modify the functioning of the status. 
It is evident that foreign studies in the present times are not focused on defending the cooperative teaching as a didactic strategy supporting learning, but they deal with the details, which make it more effective. Despite the undeniable benefits, it is absent in a homogenous form in our real school practice, which, in relation to the positive sides of the cooperative strategy of teaching, is just hardly understandable. According to the PISA SK 2006 national report, the acquired performance of our pupils reached just the average in the mathematical and natural sciences literacy. In the area of reading literacy, the acquired result was the lowest one among the European Union countries, under the average of the OECD countries. We also appeared under the average of the OECD countries in the area of solving problems. In the OECD PISA study from 2006, the Slovak education system reached the results comparable with the year 2003. However, the evaluation of these results in the international context became significantly worse in comparison with the OECD average.

Even these findings support the fact that one of the key tasks of pedagogues in the following period should be the exploration of the conditions under which the cooperative teaching will be more effective in our school practice. It is the specific development of social skills, present-day acceptance of other conditions of a successful cooperation-positive mutual dependence, an individual responsibility, face to face interaction, and implementation of feedback that ask for the pedagogues, professionals competent in the area of diagnosing the efficacy of applied didactic strategies.

\section{Goal of Research, Research Question, Research Methodology and Research Sample}

\section{Goal of Research}

By practical research, to diagnose the influences of cooperative teaching on the socio-preference relations among pupils in real conditions at selected Slovak primary schools.

\section{Research Question}

Will the use of cooperative teaching at natural history lessons positively influence the social relations of pupils in experimental classes? 


\section{Research Methodology}

We have applied the following methods:

a) Observing the reciprocity of choices and their analysis,

b) Observing the status structure of the groups of pupils, while applying the Moren sociometric method, recommended by Kollárik (1994, p. 443).

\section{Research Sample}

We diagnosed the changes in the socio-preference relations of pupils in an experimental and control group. The experimental group (ES) was formed by 68 pupils of the $5^{\text {th }}$ year (three classes of one primary school), and the control group (KS) by 76 pupils of the $5^{\text {th }}$ year (three classes of a different primary school). There were together 144 pupils. During the first half of a year, in ES, we were applying the cooperative didactic strategies at natural history lessons. The total of lessons in the aforementioned period was 40 . Within that, the cooperative strategy was fully applied at 18 lessons (45\%). During the rest of the lessons, we were suitably applying the elements of cooperative teaching.

\section{Research Results - Analysis and Interpretation of Sociometric Measuring}

We set the sociometric measuring in ES and KS even for three times during the observed period of six months; at the beginning, during and at the end of the intervention. From the point of view of a criterion type of a group members' selection, we chose an instruction defined in the following way, identical in all the three measuring records:

Write the names of classmates:

I would especially like to learn about nature that surrounds us together with:$$
2
$$

3.

At the natural history lessons I do not want to work with:

Though we did not explicitly define to pupils to place their classmates who they wanted to cooperate with according to order - e.g. on the first place a classmate they wanted to cooperate with the most, the fact that a pupil set 
somebody as the first was also taken into consideration, while allocating pupils to groups and cooperative works. By sociometry, we were observing such indicators as the index of positive sociometric status of an individual, index of negative sociometric status of an individual, index of mixed sociometric status of an individual; however, we were also evaluating compactness among the members of a group, the position of the members in it, changes in the position of a group leader... Results were processed in a form of sociometric matrices, sociograms as well as sociometric indices due to the fact that every form of sociometric data processing provides a pedagogue in practice with a source of different information.

\subsection{Sociometric Matrices}

Besides the fact that the sociometric matrices introduced us into the situation of the sociometric positions of pupils in classes in a particular period, they became a base for further calculations. In this way, the construction of sociometric matrices enabled us to read some elementary data about the position of particular pupils, number of negative choices and class sociopreference structure.

\subsection{Sociograms}

Although the sociograms of a larger group may seem non-transparent at the first sight, we used them for a faster determination of some data (e.g. number of the mutual choices of members, intensive relations among certain group members, existence of subgroups). They were necessary for a transparent determination of a number of all choices and number of mutual choices in a group. The position of a personality in a subgroup of personal mutual relations is not actually delimited only by its status, but also by its reciprocity and the symmetry of relations with other group members. According to Kolominský (1980), the structure of personal mutual relations consists of two principal variables:

1. Sociometric status of an individual

2. Indicator of its relations' reciprocity that functions in a sociometric choice as a reciprocal choice. The phenomenon of emotional preference sympathy reciprocity and interpersonal attitude, manifested in a mutual choice, can be analysed in two interlinked and at the same time relatively independent views:

One's own personality aspect - it is characterized by the presence or absence of reciprocity, i.e. a number of reciprocal choices, reciprocal selec- 
tion and the stability of reciprocity. These phenomena are considered by Kolominskij as an important characteristic of the state of personality reciprocal choices with other group members.

Group aspect - (it is introduced as a primary one) - it is perceived as a summary expressio-n of reciprocity in a particular group.

We presupposed that after applying cooperative strategies at natural history lessons in experimental classes within solving cooperative tasks, the increase of a number of interactive contacts would be appearing. These facts will be manifested by the increase of a number of reciprocal choices of experimental group members. On contrary, we expected that the dynamism of reciprocal relations would not be so distinct in the control group with prevailing information-receptive education method.

When analysing the entrance, running and output sociogram, we noticed changes in the number of reciprocal choices. Relations' reciprocity contributes to increasing the extent of emotional group members self-feeling, which is to a great extent also manifested in the increase of the satisfaction extent in a group, and the decrease of possible determinants of changes in the structure of reciprocal choices in a group.

We took into consideration the fact that we carried out research in the $5^{\text {th }}$-year classes during the first six months. In this time, pupils in the experimental group (ES) and also in the control group (KS), after completing the first grade of a primary school, were coming to the second grade of a primary school with a new structure of classmates. They were creating new groups in the class, were forming unwritten class rules, and an overall class climate was formed. That is why we were even more interested in how these facts would be displayed.

All the pupils exploited their opportunity to select three classmates who they were willing to work with and one pupil who they did not want to cooperate with. A significant output for us was represented by an indicator, which determines the percentage of reciprocal choices from the overall number of choices in a particular group. This indicator was labelled for our purposes as ISvv.

number of reciprocal choices 100

$\mathrm{ISvv}=\frac{}{\text { number of all choices }}$ 
Table 1: Reciprocal choices of group members

\begin{tabular}{|c|c|c|c|c|c|c|c|c|c|}
\hline & \multicolumn{9}{|c|}{ Experimental group } \\
\hline & \multicolumn{3}{|c|}{ ES A - 23 pupils } & \multicolumn{3}{|c|}{ ES B - 23 pupils } & \multicolumn{3}{|c|}{ ES C - 22 pupils } \\
\hline & $1 \mathrm{ST}$ & $2 \mathrm{ST}$ & $3 \mathrm{ST}$ & $1 \mathrm{ST}$ & $2 \mathrm{ST}$ & $3 \mathrm{ST}$ & $1 \mathrm{ST}$ & $2 \mathrm{ST}$ & $3 \mathrm{ST}$ \\
\hline ISvv (\%) & 23.9 & 18.2 & 20.0 & 25.8 & 27.4 & 23.2 & 29.8 & 19.0 & 26.1 \\
\hline \multirow[t]{4}{*}{$\begin{array}{l}\text { Enduring } \\
\text { relations }\end{array}$} & \multicolumn{3}{|c|}{2} & \multicolumn{3}{|c|}{4} & \multicolumn{3}{|c|}{1} \\
\hline & \multicolumn{9}{|c|}{ Control group } \\
\hline & \multicolumn{3}{|c|}{ KS A - 27 pupils } & \multicolumn{3}{|c|}{ KS B - 28 pupils } & \multicolumn{3}{|c|}{ KS C - 21 pupils } \\
\hline & $1 \mathrm{ST}$ & 2ST & $3 \mathrm{ST}$ & $1 \mathrm{ST}$ & $2 \mathrm{ST}$ & $3 \mathrm{ST}$ & $1 \mathrm{ST}$ & $2 \mathrm{ST}$ & $3 \mathrm{ST}$ \\
\hline ISvv (\%) & 20.0 & 24.3 & 18.6 & 20.6 & 22.2 & 16.25 & 23.9 & 18.9 & 10.3 \\
\hline $\begin{array}{l}\text { Enduring } \\
\text { relations }\end{array}$ & \multicolumn{3}{|c|}{2} & \multicolumn{3}{|c|}{1} & \multicolumn{3}{|c|}{1} \\
\hline
\end{tabular}

$1 \mathrm{ST}$ - first sociometric test, $2 \mathrm{ST}$ - second sociometric test, $3 \mathrm{ST}$ - third sociometric test, ISvv - percentage of reciprocal choices among the overall number of choices, ES A - experimental group, class A

Table 2: Reciprocal choices in ES

\begin{tabular}{|l|c|c|c|}
\hline & \multicolumn{3}{|c|}{ Experimental group in total } \\
\hline Number of pupils in total & \multicolumn{3}{|c|}{68} \\
\hline Sociometric test & 1 ST & 2 ST & 3 ST \\
\hline Number of all the choices in total & 186 & 191 & 175 \\
\hline Number of reciprocal choices in total & 49 & 41 & 40 \\
\hline ISvv (\%) & 26.3 & 21.5 & 22.9 \\
\hline
\end{tabular}

Table 3: Reciprocal choices in KS

\begin{tabular}{|l|c|c|c|}
\hline & \multicolumn{3}{|c|}{ Control group in total } \\
\hline Number of pupils in total & \multicolumn{3}{|c|}{76} \\
\hline Sociometric test & 1 ST & 2 ST & 3 ST \\
\hline Number of all the choices in total & 164 & 208 & 168 \\
\hline Number of reciprocal choices in total & 35 & 46 & 27 \\
\hline ISvv (\%) & 21.3 & 22.1 & 16.1 \\
\hline
\end{tabular}


Chart 1: Changes in the ISvv indicator in sociometric tests

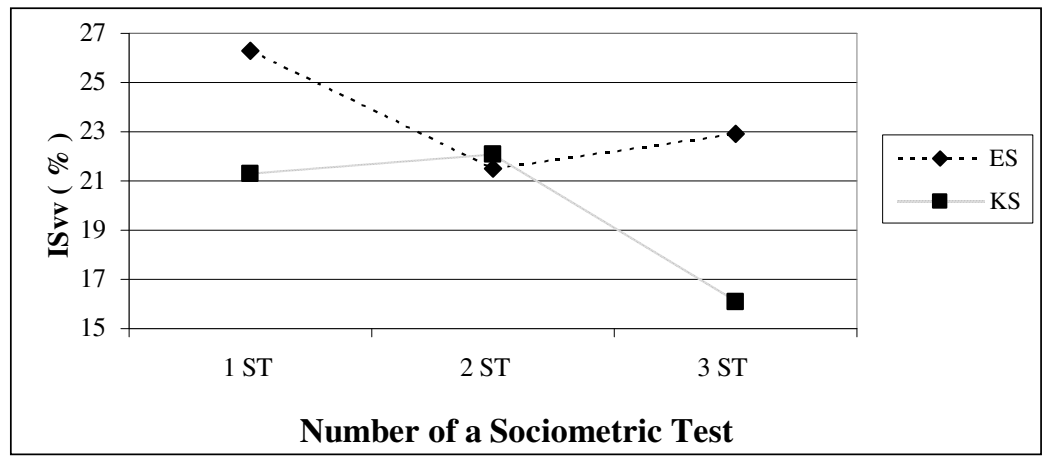

From the above tables 1, 2, 3 and chart 1 it is evident that the initial ISvv figures in ES were already higher than those in KS by $5 \%$ in average. This figure in $1 \mathrm{ST}$ in ES A was $23.9 \%$, in $2 \mathrm{ST}$ decreased to $18.2 \%$, and in $3 \mathrm{ST}$ increased again to $20.0 \%$. The initial figure in 1 ST in ES B was $25.8 \%$, in 2 ST it increased to $27.4 \%$ and in 3 ST it decreased to $23.2 \%$. The initial figure in $1 \mathrm{ST}$ in ES C was $29.8 \%$, in $2 \mathrm{ST}$ it decreased to $19.0 \%$ and in $3 \mathrm{ST}$ it increased to $26.1 \%$.

In two ES classes we noticed a decrease of the ISvv indicator in the continuous sociometric test and its consequent increase in the output sociometric test. This fact can be understood also in a sense that within the pupils' performance in groups such situations frequently appeared that also caused negative emotions in pupils, disputes, feelings of injustice or of a disagreement. This negative trend is going to be stopped and a positive influence of the cooperative teaching will begin by a long-term influence of cooperative teaching, which orients its focus towards the reflection of group processes and development of social skills of pupils in an increasing way.

To a certain extent, our findings correspond with the opinions of Petrusek (1969), who states that the sociometric status of an individual is closely related to its particular abilities and individual performance. The transmissively oriented school with the performance orientation offers more opportunities to the individuals excelling in logical thinking, mathematical and philological intelligence. Creative pupils, pupils with artistic inclinations, space and musical intelligence have fewer opportunities to develop their abilities. So, 
it is possible that these pupils, who seem to be less capable in the intentions of a traditional school, appear more frequently in negative sociometric positions due to a lower individual performance. The cooperative teaching, however, draws pupils' attention also to other personality characteristics of a man as his/her acquired knowledge and particular abilities are. It provides the classmates with an opportunity to get familiar with them in a better way, and it teaches how to appreciate the individuality.

This is even confirmed by our experience in the aforementioned classes. Pupils sensitively perceived that in case of a group work, disputes appeared more frequently, it was necessary to solve more numerous situations; the group work was more demanding for them than they were accustomed to, but at the same time more interesting. These disappointments and embarrassments connected with the cooperative teaching might have been a cause of the decreasing number of mutual choices. By a constant enforcement of positive mutual dependence, individual responsibility and specific formation of social skills, they were gradually realizing the fact that it was necessary to depersonalize, to learn how to solve problems pragmatically, to communicate and know how to appreciate their classmates. We suppose that just these facts were in the end displayed in a repeated increase of an indicator demonstrating the ratio of the overall number of mutual choices and the number of all the choices recorded in $3 \mathrm{ST}$ in two experimental groups.

This trend is also visible in case of viewing experimental groups as one unit (Table 2). ISvv is decreased from $26.3 \%$ to $21.5 \%$ and repeatedly increased to $22.9 \%$. The aforementioned interpretations are in favour of establishing cooperative pedagogical strategies at different subjects' lessons. With respect to the fact that the ISvv indicator remains on a lower level in the output sociometric test, through observing the reciprocity of choices and their analysis, it is necessary to state that: the use of cooperative teaching at natural history lessons would not considerably positively influence the social relations of pupils in experimental classes.

On the basis of measuring in KS it is clear that the initial ISvv figure in $1 \mathrm{ST}$ in KS A was $20.0 \%$, in 2 ST it was increased to $24.3 \%$, and after half a year it decreased to $18.6 \%$ in 3 ST. Similarly in 1 ST in KS B it was $20.6 \%$, in 2 ST it was increased to $22.2 \%$ and decreased to $19.3 \%$ in 3 ST. Similarly also in $1 \mathrm{ST}$ in KS C it was $23.9 \%$, it decreased to $18.9 \%$ in $2 \mathrm{ST}$ and in $3 \mathrm{ST}$ it decreased to $10.3 \%$. The fact that we recorded in two control groups a tem- 
porary increase of the ISvv figure and its consequent decrease (which was also manifested in the control group if it is considered as a unit (Table 3)), and the fact that in the third control group this figure was gradually decreasing, are interpreted in such a way that the pupils of control groups, after the initial period of getting familiar with themselves and in an effort to be included into the new class collective, will present a negative change in the structure of mutual choices in a group if they are not motivated to preserve this effort and solve conflicts in a class. By observing the reciprocity of choices in control groups, we came to a conclusion that the social dynamics in them was on one hand considerable, but in the end it was negative.

\subsection{Sociometric indices}

It deals with a numerical expression of the carried out choices, which were focused on:

a) Observing the signs of a group as a whole, e.g. its compactness, expanding...

b) Observing the sociometric status of an individual in a group of pupils at the same age.

After constructing the sociometric matrices and sociograms, the definition of sociometric indices was in the focus of our attention.

We calculated:

1. Individual indices of socio-preference relations expressing the sociometric status of an individual (Janoušek, 1986)

a) ISS - index of the positive sociometric status of an individual,

b) ISSN - index of the negative sociometric status of an individual,

c) ISSZ - index of the mixed sociometric status of an individual.

2. Group index for finding out the sociometric structure of a group (Kerlinger, in: Švec, 1998)

IS - index of compactness.

The aforementioned individual indices of socio-preference relations (besides ISSZ) appear in the interval from 0 to 1 . ISSZ appears in the interval from +1 to -1 . In the course of research, the sociometric measuring was 
repeated three times in every class and in case of a need, the composition of the groups of pupils was flexibly changed in the cooperatively working classes on the basis of the measuring results. On the basis of the ISSZ figure received by a pupil, it is possible to assign this pupil a role, which is quite stable if it is not affected (Wardová, 1994). Roles are characterized in the following way: "Stars", or leaders - pupils who are most favoured among classmates.

Unnoticed, or neglected pupils - are usually ignored by other pupils when selecting partners for a game or work. These pupils choose somebody they want to work with, however, they are rarely chosen by other pupils. Their choice is not reciprocal.

Rejected ones (refused ones) - they are not chosen by others on purpose because it is difficult to work with them, or they do not have sufficient abilities for a good game and for finishing, for instance, a project.

Pupils with mutual positive relations create a clique in a class. This little group chooses exclusively other members of the clique. Cliques consist of two or four pupils; they are most often the arrangements of girls.

Isolates (not accepted) - they are separated from others on the basis of their behaviour, personal qualities, or a lack of social competences, or a study success. They can choose from a restricted number of pupils in a group, but they are never chosen by the others.

\section{Individual Indices of Socio-Preference Relations}

On the basis of the sociometric matrices and sociograms analysis we interpreted the status structure of personal mutual relations in a group, we were comparing changes in the status structure in the initial (1 ST), continuing (2 ST) and output sociometric test (3 ST). According to the acquired ISSZ level, we classified the group members as: 1. Stars, 2. Preferred, 3. Accepted, 4. Not accepted, 5. Rejected (according to Volková, as she is introduced by Kolominskij (1980)).

Table 4: Clasification of group members on the basis of ISSZ

\begin{tabular}{|l|c|c|}
\hline \multicolumn{1}{|c|}{ Sociometric status } & \multicolumn{2}{c|}{ Mixed sociometric status figure (ISSZ) } \\
\hline 1. Stars & +0.20 & and more \\
\hline 2. Preferred & +0.05 & 0.19 \\
\hline 3. Accepted & -0.04 & +0.04 \\
\hline 4. Not accepted & -0.05 & -0.19 \\
\hline 5. Rejected & -0.20 & and less \\
\hline
\end{tabular}


According to the acquired level of the social status, we elaborated a status structure of groups. While defining it, we followed ISSZ - index of the mixed sociometric status of an individual. The figures ISS - index of the positive sociometric status of an individual and ISSN - index of the negative sociometric status of an individual, were used by us as orientation indices throughout the period of experiments. We compared the status structure of groups in ES and KS in the initial, continuing and output sociometric test (1 ST, $2 \mathrm{ST}$ and $3 \mathrm{ST}$ ).

Table 5: Status structure in ES and KS in the initial, continuing and output sociometric test (ISSZ 1, ISSZ 2, ISSZ 3)

\begin{tabular}{|l|c|c|c|c|c|c|c|c|c|}
\hline & \multicolumn{9}{|c|}{ Experimental group } \\
\hline $\begin{array}{l}\text { Sociometric } \\
\text { position }\end{array}$ & \multicolumn{3}{|c|}{ ES A - 23 pupils } & \multicolumn{2}{|c|}{ ES B - 23 pupils } & \multicolumn{3}{c|}{ ES C - 22 pupils } \\
\hline & ISSZ 1 & ISSZ 2 & ISSZ 3 & ISSZ 1 & ISSZ 2 & ISSZ 3 & ISSZ 1 & ISSZ 2 & ISSZ 3 \\
\hline Stars & 4 & 5 & 3 & 3 & 5 & 4 & 1 & 4 & 2 \\
\hline Preferred & 15 & 12 & 13 & 13 & 11 & 12 & 18 & 15 & 13 \\
\hline Accepted & 2 & 2 & 4 & 3 & 3 & 2 & 1 & 1 & 4 \\
\hline $\begin{array}{l}\text { Not } \\
\text { accepted }\end{array}$ & 2 & 4 & 2 & 4 & 3 & 5 & 1 & 1 & 2 \\
\hline Rejected & 0 & 0 & 1 & 0 & 1 & 0 & 1 & 1 & 1 \\
\hline & & & & \multicolumn{7}{|c|}{ Control group } & & & \\
\hline $\begin{array}{l}\text { Sociometric } \\
\text { position }\end{array}$ & KS A - 27 pupils & KS B - 28 pupils & KS C - 21 pupils \\
\hline & ISSZ 1 & ISSZ 2 & ISSZ 3 & ISSZ 1 & ISSZ 2 & ISSZ 3 & ISSZ 1 & ISSZ 2 & ISSZ 3 \\
\hline Stars & 0 & 2 & 1 & 2 & 1 & 4 & 4 & 5 & 3 \\
\hline Preferred & 12 & 16 & 12 & 13 & 16 & 12 & 10 & 9 & 10 \\
\hline Accepted & 14 & 7 & 11 & 8 & 8 & 7 & 5 & 4 & 6 \\
\hline $\begin{array}{l}\text { Not } \\
\text { accepted }\end{array}$ & 0 & 1 & 3 & 5 & 1 & 4 & 1 & 2 & 0 \\
\hline Rejected & 1 & 1 & 0 & 0 & 2 & 1 & 1 & 1 & 2 \\
\hline
\end{tabular}

The mentioned figures were summarized in the table, which transparently records the changes in the status structure of groups. 
Table 6: Status structure of groups in the initial, continuing and output test in ES (1 ST - first sociometric test, ES A - experimental group, class A)

\begin{tabular}{|l|c|c|c|c|}
\hline \multicolumn{1}{|c|}{ Status position } & Group & 1 ST & 2 ST & 3 ST \\
\hline Positive & ES & 21 & 19 & 20 \\
Negative & A & 2 & 4 & 3 \\
\hline Positive & ES & 19 & 19 & 18 \\
Negative & B & 4 & 4 & 5 \\
\hline Positive & ES & 20 & 20 & 19 \\
Negative & C & 2 & 2 & 3 \\
\hline
\end{tabular}

Table 7: Status structure of groups in the initial, continuing and output test in KS (1 ST - first sociometric test, KS A - control group, class A)

\begin{tabular}{|l|c|c|c|c|}
\hline \multicolumn{1}{|c|}{ Status position } & Group & 1 ST & 2 ST & 3 ST \\
\hline Positive & KS & 26 & 25 & 24 \\
Negative & A & 1 & 2 & 3 \\
\hline Positive & KS & 23 & 25 & 23 \\
Negative & B & 5 & 3 & 5 \\
\hline Positive & KS & 19 & 18 & 19 \\
Negative & C & 2 & 3 & 2 \\
\hline
\end{tabular}

Table 8: Status structure of groups in the initial, continuing and output test in ES and KS

\begin{tabular}{|c|l|c|c|c|}
\hline Group & \multicolumn{1}{|c|}{ Status position } & 1 ST & 2 ST & 3 ST \\
\hline \multirow{2}{*}{ ES in total } & Positive & 60 & 58 & 57 \\
\cline { 2 - 5 } & Negative & 8 & 10 & 11 \\
\hline \multirow{2}{*}{ KS in total } & Positive & 68 & 68 & 66 \\
\cline { 2 - 5 } & Negative & 8 & 8 & 10 \\
\hline
\end{tabular}

If we assess ES a KS as two units (Table 8), we find out that the number of pupils with a negative sociometric position increases slightly, and the number of pupils with a positive sociometric position decreases in both groups.

We will try to find the answer for a question why the ISSZ figures in KS, but also in ES, were just minimally changed in the second and third sociometric test in comparison with the first sociometric test. This fact surprised us even more because we expected that the changes would also be more distinct in KS. In relation to the fact that the pupils in ES and also KS started at- 
tending the fifth grade of a primary school, and they were being included in a new collective, we expected that the process of a group forming would not be possible without conflict situations, the definition of class norms, and just a consequent possible functioning of groups in it, and it would be displayed on the fluctuating figures of the individual indices of socio-preference relations. The tables, however, show that the ISSZ figures were changing in both groups in a minimal way.

The criterion of our sociometric test focused on the choice of classmates a pupil wanted, or did not want to work with at the lessons of natural history. Since the pupils of control groups cooperated at lessons just minimally (if it is possible to speak about any cooperation at all), we suppose that they were choosing the classmates with whom they could be able to form groups capable of succeeding in performance oriented tasks. At the same time, the students in KS did not work on any common tasks, so they did not have any reason to change radically the preference of certain persons, but they were predominantly choosing the same pupils characteristic by an outstanding activity, or outstanding grades.

According to our opinion, all the pupils had an opportunity to succeed in experimental groups within the half a year period of the cooperative teaching implementation. Some pupils were surprised by themselves, by their successful work in a small group. Other pupils skilfully managed the organization of the work in a group, were helpful, cooperating, and the other pupils also noticed, by a constant reflection of groups' performance, what could be appreciated on their effort. While working on cooperative tasks, pupils realized the inevitability of cooperation with the others, and the fact that the result of a group is dependent on a particular result of an individual. The less active pupils and in grades less efficient pupils, encouraged by this fact, many times displayed their outstanding organizing activities in a group. It was many times them who reduced the load of the work in a group, and through their optimism, they arranged a nice atmosphere in working on tasks. They sometimes surprised the others with their creativity and originality of viewing a discussed problem. While reflecting the group efforts, they several times interested the others with their "pragmatic view of" the group work. So, the other pupils could experience them even in situations when their individual abilities were clearly excelling. 
However, we also noticed negative reactions. The pupils on their own (not just the teachers) have a problem to change an opinion on another man, if they have already fixed him/her as the one who is silent when being examined, does not answer questions, does not reproduce the taught knowledge, has worse grades. It is in the pedagogical competence and professionalism of a pedagogue to process these situations correctly, e.g. not to overate the performance of pupils, not to stress these uselessly, but to make them visible in a reasonable extent. Otherwise, a pedagogue may cause in other pupils an aversion against these pupils. We presupposed that the influence of the cooperative teaching would be intensive in such an extent that pupils would realize the value of those pupils who had worse grades and, in a traditionally perceived teaching, were not considered successful. On the other hand, during the period of forming groups, creating rules within them (which was manifested quite turbulently in some groups), learning how to communicate and respect the others, we took a difficult road. Our goal was not to look like there were no problems among the members of groups, but to teach pupils how to solve these problems, which is as to the pupils at the age of 10-11 a demanding task for every pedagogue. It was probably this fact that was projected (besides the others) into the reality that the number of pupils with positive status structure was not increased. Since we witnessed the pupils' everyday work on themselves, solutions of many pleasant and unpleasant situations that do not appear in a traditionally perceived teaching, we may say that the ISS figures did not surprise us too much. Our interpretations would rather lead to the fact that if pupils worked actively in groups within the cooperative teaching, the reality that the ISSZ figures were, despite the conflicts, changing is of stimulating importance.

This reality can be also explained by the fact that natural history was the only subject carried out by cooperative teaching for the ES pupils. We suppose that the quantity proportion of traditionally taught lessons (considering at the same time also a lesson ratio of the other subjects in the fifth year) and the lessons with cooperative teaching was not then convenient in a sense of the possibility of causing a change in the pupils' status position. Since we did not want to use cooperative teaching at natural history lessons at any pain, but we used it with a detached perspective where it was possible in relation to the focus of a lesson topic, we consider our plan to influence the status position of pupils as maximally arranged. It may be said that we wanted to 
verify in this way whether the application of cooperative teaching in the given extent, to reach this effect indeed, would not be sufficient. We may state that by observing the status structure of pupil groups throughout the experiment duration and by its analysis we stayed that: the use of cooperative teaching at natural history lessons would not considerably positively influence the social relations of pupils in experimental classes.

However, we may state that we did not even notice a change in social relations in $\mathrm{KS}$ in a distinctively positive or negative direction. However, on the basis of observing the status structure, it is evident that it is necessary to observe even these conclusions from several perspectives. It is essential to perceive also those tendencies to which the conclusions lead, even if they are not clear.

\section{Group Index of Compactness}

$I S$ - index of compactness - it provided us with the information on a situation in a group without determining a direction of choices because it is focused on observing the signs of a group as one unit. With the increasing figure of IS, the group compactness is increased as well.

Table 9: Index of compactness in ES

\begin{tabular}{|c|c|c|c|c|c|c|c|c|c|}
\hline \multirow{4}{*}{$\begin{array}{l}\mathscr{\Omega} \\
4 \\
0 \\
0 \\
0 \\
0\end{array}$} & \multicolumn{9}{|c|}{ Experimental group } \\
\hline & \multicolumn{3}{|c|}{ ES A - 23 pupils } & \multicolumn{3}{|c|}{ ES B - 23 pupils } & \multicolumn{3}{|c|}{ ES C - 22 pupils } \\
\hline & $1 \mathrm{ST}$ & $2 \mathrm{ST}$ & $3 \mathrm{ST}$ & $1 \mathrm{ST}$ & $2 \mathrm{ST}$ & $3 \mathrm{ST}$ & $1 \mathrm{ST}$ & $2 \mathrm{ST}$ & $3 \mathrm{ST}$ \\
\hline & 0.063 & 0.047 & 0.047 & 0.063 & 0.067 & 0.063 & 0.074 & 0.052 & 0.052 \\
\hline
\end{tabular}

Chart 2: IS changes in the sociometric tests in ES

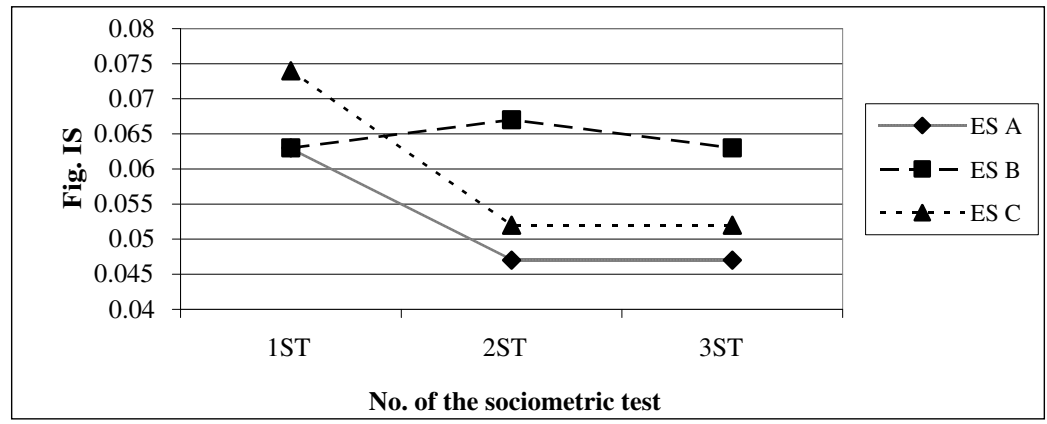


Table 10: Index of compactness in KS

\begin{tabular}{|c|c|c|c|c|c|c|c|c|c|}
\hline \multirow{4}{*}{ 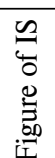 } & \multicolumn{9}{|c|}{ Control group } \\
\hline & \multicolumn{3}{|c|}{ KS A - 27 pupils } & \multicolumn{3}{|c|}{ KS B - 28 pupils } & \multicolumn{3}{|c|}{ KS C - 21 pupils } \\
\hline & $1 \mathrm{ST}$ & $2 \mathrm{ST}$ & $3 \mathrm{ST}$ & $1 \mathrm{ST}$ & $2 \mathrm{ST}$ & $3 \mathrm{ST}$ & $1 \mathrm{ST}$ & $2 \mathrm{ST}$ & $3 \mathrm{ST}$ \\
\hline & 0.031 & 0.051 & 0.031 & 0.034 & 0.048 & 0.034 & 0.052 & 0.048 & 0.14 \\
\hline
\end{tabular}

Chart 3: IS changes in sociometric tests

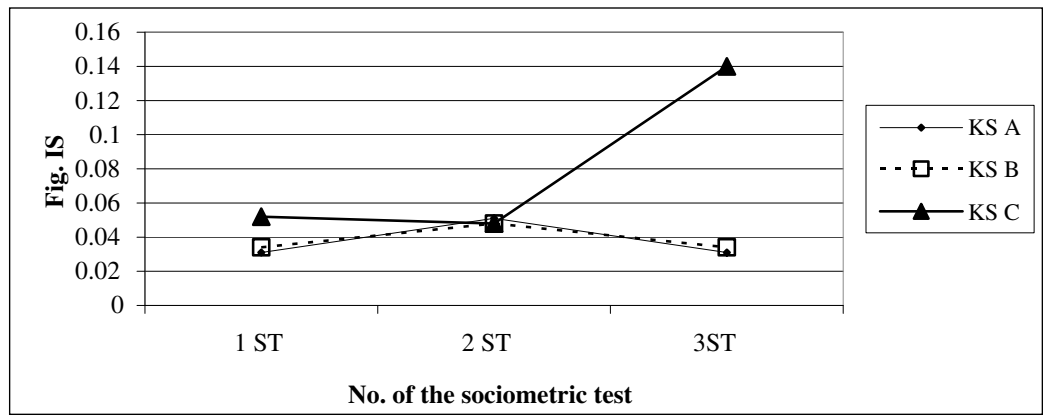

Our interpretations of the IS changes are parallel with the interpretations following from the observation of changes in the ISS, ISSN and ISSZ figures and the observation of the reciprocity of particular members' choices. It is only a purpose of using these figures that may change, and it is especially the index of compactness that provides quick information on a situation in a class. However, it is not sufficient for a deeper analysis of relations in a group.

\section{Discussion}

Similarly as in case of previous research, the increase of the number of choices in a group was also recorded after applying education dramatics in a school club for children, while applying cooperative approaches by Kovalčíková (2002) and Jablonský (2006), who implemented cooperative teaching at the lessons of ethical education. Kovalčíková (2002) confirmed that the implementation of personal education and social education in a group of pupils through dramatic plays - the intervention with the use of 
cooperative and experience oriented pedagogical strategies - evokes changes in the status structure of a group in a positive way because the acceptation and appreciation of the value of pupils are increased. That optimizes in the end the interpersonal relations in a class, creates conditions for suitable social climate and atmosphere as well, and the atmosphere influences the teaching efficacy increase. However, in our research, we were applying the cooperative approach along with educating pupils in the area of natural history, so, we used it as an instrument, not as a goal. According to Wardová (1995), it is crucial to uncover the social structure of a class, to identify the roles being fulfilled by pupils in a class, and to use an opportunity that despite the stability of roles there are possibilities how to affect them. However, a pedagogue must go through a strategy in a thorough way, beginning with the observation of a group's structure, continuing with the perception and evaluation of certain situations, up to the critical analysis of his/her own procedures on the basis of feedback. Saleh - Lazonder-Ton (2005), examining social interactions, found out that the heterogeneous groups increase an extent of individual work, while the homogenous groups lead to a more collaborative work in a relatively more frequent way.

On the basis of our experience with cooperative teaching we state that using cooperative teaching only at the lessons of natural history was not sufficient to reach the influencing of a climate in classes (in the majority of variables). It is significant to realize that if a teacher at the second grade of primary schools wants to influence the social climate in classes and does not have his/her colleagues' support, his/her efforts need not reach an expected effect. We suppose that the quantity proportion of traditionally taught lessons (thinking at the same time about a lesson portion of other subjects for the fifth-year pupils) and the lessons with cooperative teaching was not then positive in a sense of the functioning of a change in the pupils' status position.

That is why we stress that if our schools are supposed to face innovations, they should be systemic and premeditated; they should be intermingled with all the teaching subjects. Otherwise, the introduction of special subjects for teaching social skills to pupils will have no reason. If these skills are not to be integrated into all subjects, they will not be comprehended, and will stay forgotten. It would be needy to consider the presence of a social pedagogue at several schools, for whom general education principles mean a starting point. These are e.g. the principle of respecting a personality, individual approach, 
the principle of personality formation in a formation group (Zemančíková, 2009).

We recommend to pedagogues to concentrate on diagnosing the sociometric structure of a class. Under the influence of the presented arguments, we even consider necessary that the research activities should gradually become an obvious part of pedagogical competences.

\section{References}

COHEN, E. G. Restructuring the Classroom: Conditions for Productive Small Groups. Review of Educational Research, 1994, vol. 64, no. 1, pp. 1-35.

GILLIES, R. M. - ASHMAN, A. F. Behavior and Interaction of Children in Cooperative Groups in Lower and Middle Elementary Grades. British Journal of Educational Psychology. 1998, vol. 90, no. 4, pp. 746-757.

GILLIES, R. M. - ASHMAN, A. F. The effect on gender and ability on students' behaviours and interactions in classroom-based work groups. British Journal of Educational Psychology. 1995, vol. 65, pp. 211-225.

GREER, L. L. - JEHN, K. A. - MANNIX, E. A. Conflict Transformation A Longitudinal Investigation of the Relationships Between Different Types of Intragroup Conflict and the Moderating Role of Conflict Resolution. Small Group Research. 2008, vol. 39, no. 2, pp. 278-302.

JABLONSKÝ, T. Kooperatívne učenie vo výchove [Cooperative Teaching in Education]. Levoča: MTM, 2006. ISBN 80-89187-13-7.

JANOUŠEK, J. Metody sociální psychologie [Methods of Social Psychology]. Praha: SPN, 1986.

JOHNSON, D. W. - JOHNSON, R. T. Social Skills for Succesful Group Work. Educational Leadership. 1990, vol. 47, no. 4, pp. 29-33.

KOLLÁRIK, T. Sociometria v škole [Sociometry in Schools]. Pedagogická revue. ISSN 1335-1982, 1995, vol. 46, no. 9-10, pp. 443-450.

KOLOMINSKIJ, J. L. Psychológia vzájomných vztahov v malých skupinách [Psychology of Mutual Relations in Small Groups]. Bratislava: SPN, 1980.

KOSOVÁ, B. Základné pojmy a vztahy v edukácii [Essential Notions and Relations in Education]. Banská Bystrica: PdF UMB, 2007. 162 pp. ISBN 978-80-8083-525-5.

KOVALČÍKOVÁ, I. Vplyv výchovnej dramatiky v školskom klube detí na zmenu sociopreferenčných vztahov v školskej triede [Influence of Edu- 
cational Dramatics in a School Club on the Change of Socio-Preferential Relations in a School Class]. Pedagogická revue. ISSN 1335-1982, 2002, vol. 54. no. 2.

LAŠEK, J. Komunikační klima ve středoškolské tříde [Communication Climate in a Secondary School Class]. Pedagogika, 1994, vol. 44, no. 2, pp. 155-162.

MCGEEHAN, A. R. et al. Nonlinear Dynamics of Individual and Interpersonal Conflict in an Experimental Group. Small Group Research. 2008, vol. 39, no. 2, pp. 150-178.

MURPHYOVÁ, C. Učitel' ako výskumník: nachádzanie odpovedí v triede. [Teacher as a Researcher: Finding Answers in a Class]. Pedagogická revue, ISSN 1335-1982, 1995, vol. 46, no. 9-10, pp. 469-474.

Národná správa PISA SK 2006 [PISA SK 2006 National Report] [online]. [cit. 2010-10-8] Dostupné na [Available at]: http://www.nucem.sk/documents//27/medzinarodne_merania/pisa/realizovane_studie_pisa/2006/ PISA_2006.pdf.

SALEH, M. - LAZONDER, A. W. - DE JANG TON. Effects of within class ability grouping on social interaction, achievement and motivation. Instructional science: An International Journal of Learning and Cognition. 2005, vol. 33, no. 2, pp. 105-119.

SEEBAUEROVÁ, R. Školská a triedna klíma: Rakúsky pohl'ad [School and Class Climate: An Austrian View]. Pedagogická revue, ISSN 1335-1982, 2005, vol. 58, no. 4, pp. 349-361.

SPENCER, M. S. Et al. Outcome Evaluation of the Intergroup Project. Small Group Research. 2008, vol. 39; no. 1, pp. 82-103.

ŠVEC, S. Základné pojmy v pedagogike a andragogike [Essential Notions in Pedagogy and Andragogy]. Bratislava: Iris, 1995. ISBN 80-89018-31-0.

WARDOVÁ. M. A. Učitel'ovo meranie klímy vo vlastnej triede [Teacher's Measuring of a Climate in His/Her Own Class]. Pedagogická revue. ISSN 1335-1982, 1995, vol. 46, no. 9-10, pp. 460-468.

ZELINA, M. Stratégie a metódy rozvoja osobnosti dietata [Strategies and Methods of a Child's Personality Development]. Bratislava: Iris, 1996. ISBN 80-967013-4-7.

ZEMANČÍKOVÁ, V. Otázky školskej sociálnej pedagogiky [Questions of School Social Pedagogy]. In Acta Humanica, Žilina: FPV KPŠ ŽU, ISSN 1336-5126, 2009, vol. 2, pp. 326-339. 


\section{Contact}

Mgr. Jana Trabalíková, PhD.

Department of Educational Studies

Faculty of Humanities

Žilina University

Univerzitná 8215/1

01026 Žilina

Slovakia

e-mail: jana.trabalikova@fhv.uniza.sk 